Special Issue on Federalism and Conflict Management edited by Neophytos Loizides, losif Kovras and Kathleen Ireton.

\title{
SOMALIA AND SOMALILAND: THE TWO EDGED SWORD OF INTERNATIONAL INTERVENTION
}

\author{
by David Kenning* \\ * Queen's University Belfast, Ireland \\ Email: dkenning01@qub.ac.uk
}

\begin{abstract}
Since the collapse of the state in Somalia in 1991 the country has been the recipient of numerous international interventions and operations but has not as yet reached a sustainable peaceful settlement, despite at one point costing the UN almost two billion dollars a year in its operations. In contrast Somaliland, the area that seceded in the north, despite not being recognised by international governments and having been on the brink of several civil wars, has reached a level of political reconciliation and economic growth that compares favourably to the rest of Somalia. This article argues that the international actors' misinterpretation of Somali social and political organisation during intervention, Somaliland's ability to engage in a form of democracy that is based on traditional politics and the different experience the area had during colonialism has meant that its society has reached an unlikely level of peace and reconciliation.
\end{abstract}

Keywords: International intervention, Somalia, Somaliand

Kenning, D. 2011, "Somalia and Somaliland: The two edged sword of International intervention", Federal Governance, vol. 8 no. 2, pp. 63-70. 


\section{About Federal Governance}

Federal Governance is an online graduate journal on theory and politics of federalism and multilevel governance. Its mandate is to engage the global federalism community and reach out to outstanding graduate students interested in federalism and multi-level governance. By providing a platform for graduate students to have early success in their careers, Federal Governance seeks to promote and sustain interest in federalism and multi-level governance research among graduate students. Allied with the Forum of Federations and founding partner, Institute of Intergovernmental Relations at Queen's University; Federal Governance aims to contribute to a global dialogue on federalism.

Co Chairs, Advisory Committee:

Publisher:

Managing Editor:

Associate Editors:

\author{
Rupak Chattopadhyay and Christian Leuprecht \\ Forum of Federations \\ (Rupak Chattopadhyay and Rod Macdonell) \\ Annegret Eppler \\ Joshua Cerovski, Dominic Heinz, \\ Eva-Maria Maggi and Victoria Tait
}

\section{Terms of Use}

Your use of this Federal Governance article indicates your acceptance of Federal Governance's Terms and Conditions of Use, available at www.federalgovernance.ca/terms. Federal Governance's Terms and Conditions of Use provides that you may use Federal Governance content only for personal, academic and non-commercial use. Each copy of any part of this Federal Governance article must contain the same copyright notice that appears on the screen or printed page of such transmission. 


\section{Introduction}

Since 1991 Somalia has been the archetypal failed state. Several attempts to create a centralised democracy have failed. The current government is on the brink of collapse, overtaken yet again by an Islamist insurgency despite the support of an Ethiopian military intervention since December 2006 (International Crisis Group 2008, 1). This reads as a familiar scenario for a country which has received millions of dollars of aid including three different intervention programs during the first half of the 1990's alone. The country has deteriorated in condition since President Siyad Barre's government was overthrown in 1991 and currently sits as an 'empty shell' on the horn of Africa. Whilst the initial international relief and security operation that immediately followed brought much needed humanitarian aid to the population, it has failed to bring an end to the inter-clan militia conflict (Somalia-Canada Institute 1999). FitzGerald notes that at the beginning of 2005 the closest thing to a central government in the capital Mogadishu had been evicted from a Nairobi hotel and faced riots when its officials ventured into the old capital (Reno 2006, 147). However, in Somalia an intriguing situation has emerged. Although former British Somaliland has been part of Somalia since 1960, it has built and maintained a level of peace and reconciliation that compares favourably with the rest of the country. The Canadian based NGO 'PACNET' describes the country as one of "stark contrast-between the troubled central and southern regions and the stable and peaceful north" (Somalia-Canada Institute 1999). The question is then how such different circumstances can exist within a country that has received so much attention from the international community, including a UN peacebuilding operation, UNOSOM II, in 1993. This essay argues that Somaliland's impressive condition since its claim to independence in 1991 is a result of the mismanagement of the conflict by the international community when they intervened in Somalia in the early 1990's as well as Somaliland's use of traditional clan politics as a base for building democracy and lastly, the legacy of colonialism.

\section{International Intervention in Somalia and current situation}

Between 1992 and 1995 there were three different interventions that attempted to help the situation in Somalia. ${ }^{1}$ Although beginning simply as a humanitarian effort by the international community, intervention culminated in what would become a peacebuilding operation. However the motivations, attitudes and actions during these operations have had a large influence not only on Somalia's current situation but also,

1 These included 'United Nations Operation in Somalia I' (UNISOM I), the 'United Task Force' (UNITAF) and 'United Nations Operation in Somalia II' (UNISOM II). 
arguably, have led to grave consequences in subsequent global events such as the genocide in Rwanda. The motivations behind UNISOM I and UNITAF, it can be argued, were ill thought out and reactionary in nature. Regarding UNISOM I Ismail Ahmed and Reginald Green note that belated international media coverage of the crisis played a key role in triggering an international response and that the "decision to intervene was tragically late" (Ahmed and Green 1999, 121). The 'official' motivation for the operation was to provide a humanitarian response in order to help the hundreds of thousands of people that were displaced and starving because of famine and the civil war. However, James Mayall argues that the "involvement of the UN in Somalia was a product of the new international climate" created after the end of the Cold War and the success of 'Operation Desert Storm' (Mayall 1996, 94). The motivation for UNITAF was no better. Brune argues the US judged Somalia by the television pictures reaching its homes. These images captured the suffering and starving citizens, but not the savage reality of the young gangs (Brune 1998, 19). Therefore, the motivations behind the initial interventions were based on a temporary political climate and the sympathy toward a people and a state that the actors knew little about. If the initial foray into Somalia had been a more calculated and a more encompassing mission motivated by the will to create sustainable peace through flexible means or at least control harmful domestic events in the country, it is possible that today the situation would be much different.

To further comprehend why there is relative peace in Somaliland compared to the rest of Somalia an analysis of the actions taken during these initial interventions must be completed as they laid the foundations for the current situation. It becomes clear from looking at the actions of the UN that they lacked in-depth knowledge of the political climate in which they were working. Its efforts were almost exclusively based in the capital of Mogadishu and the organisation worked exclusively with warlords in its attempt to negotiate a peace during UNOSOM II, creating an even more complicated situation. The UN's actions were exactly like those of an organisation who were not experienced in conducting this kind of intervention. For example they decided to run the humanitarian operation directly from Mogadishu, despite the previous war in the south displacing approximately 1.7 million people, a third of the southern population. To have an influx of that proportion of people coming into a war torn capital was simply logistically naïve (Ahmed and Green 1999, 121). Instead of using a centralised governmental blueprint for the operation, the UN may have had greater success in its efforts if it either focused more on reaching the people in Southern Somalia via a federal approach to government and aid.

Furthermore, 'Operation Restore Hope', launched in 1992, resulted in a contradictory multi-mandated intervention involving peacemaking, peace keeping and peace enforcement activities (Ahmed and Green, 122). At one point there were three distinct forces operating in Mogadishu with three distinct chains of command (Dobbins 
2003, 62). The consequences of this are clear from Brune's argument that not only was UNISOM I handicapped because divisions between UN relief groups failed to coordinate activities but the US also seemed to misunderstand the true nature of UNISOM I's troubles. It appears that it failed to grasp the vital connection between Somalia's political anarchy and the attainment of success for their 'humanitarian' mission, placing Clinton's early exit strategy in a degree of turmoil (Brune 1998, 17-19). Without coherence in activities during UNISOM II, it comes as little surprise that the interveners were unable to come to a peaceful agreement. This became even more difficult after the US announced its withdrawal in 1994 and the subsequent downsizing of UNISOM II's operations.

In terms of reaching a peaceful conclusion to events the interveners took two major actions which can help explain why there is precious little peace in southern Somalia today. First it can be said that UNISOM II, although essentially a nation building operation, devoted little time or effort to achieving societal change or political settlement. The dependence on warlords to distribute humanitarian relief merely concentrated political and economic power in the hands of unscrupulous armed individuals (Dobbins et al 2003, 67). Due to the fact that UNOSOM I was simply a humanitarian operation involving few troops, the UN had to pay money to bodyguards in order to ensure the distribution of its aid. This not only proved expensive but encouraged a war economy by paying large amounts of money to militia, and discouraged disarmament (Ahmed and Green 1999, 121). This suggests that before trying to build peace in Somalia the UN effectively funded the warlords that were previously fighting in the civil war before less than two years later attempting to forcibly disarm. These actions simply encouraged violent clashes and, it can be argued, caused an arms race between the different clans in southern Somalia. This gives an indication to why, when the interveners pulled out, peace has not been reached whilst groups maintain armed. A problem that still faces the Ethiopian military currently stationed in Somalia (BBC 2007).

It is not just an over reliability on warlords during intervention that helps to explain the differences between Somalia and Somaliland. A second factor is the belief of those involved in UNOSOM II who decided that the best way to gain peace was to kill General Mohammed Farrah Aideed. ${ }^{2}$ This proved to be a fatal mistake. As Mayall notes, by attacking a party of Pakistani 'blue berets', Aideed successfully lured Admiral Howe, the UN's Special Representative for Somalia, into a bitter confrontation in which "every raid on southern Mogadishu [by US/UN forces] earned him more support." The UN seemed insensitive to fact that its attempts to capture Aideed would inevitably be

2 General Aideed was both a main instigator of the civil war and one of the key individuals embroiled in a fight for domination of the state. When United Nation troops left in 1995 it was Aideed who proclaimed himself President of Somalia in 1995, lasting until August 1996. 
interpreted as an attack on his clan group with the deliberate intention of favouring their rivals (Mayall et al. 1996, 116-117). Furthermore, seemingly without consideration for the consequences, large numbers of the Somali ancillary staff were recruited by the UN from Aideed's clan helping to both finance Aideed's operation and supply him with valuable intelligence. An inadequate number of qualified Somali advisors were recruited and Mayall notes that generally UN officials could hardly have been more inadequately briefed about society and culture (Mayall 1996, 121). Not only did the UN assist Aideed in gaining more internal support amongst Somalis but it also meant that throughout the country the accompanying bloodshed meant that any subsequent international intervention has been looked on with distrust by Somali citizens. ${ }^{3}$

A third course of action taken by the UN/US forces that has since had a destabilizing effect on the political and security situation in southern Somalia is the attitude that the organisations displayed toward the conflict. The UN and the US both committed themselves to an intervention on the reasoning that it was morally righteous and that it would be fairly easy and quick to complete. However Ahmed and Green note that understanding clan and lineage in contemporary Somali politics, while necessary, is not sufficient to unlock their social and political organisation (Ahmed and Green 1999, 115). In a sense, therefore, they showed a lack of respect to Somali political and social make up, because despite having a lack of information during the critical period of the crisis, they still failed to consult NGO's that were present at the time. This was a display of arrogance, a trait that has plagued western actors in African states that are seen to have 'lesser' political and social frameworks (Ahmed and Green 1999, 122). ${ }^{4}$ This is further illustrated by the continuing insistence of the international community to base sponsored peace talks outside Somalia itself. This decision creates a government that has no legitimate rule over the population and lacks popular support. In 2007, for example, President Yusuf, encouraged to set up an inclusive government returned to Mogadishu for the first time since being elected president in peace talks in 2004 (BBC 2007). It seems the lessons from 1992-1995 have not been learned as the West still actively seeks to impose a centralised democratic government in Somalia. It seems that the possibility of including any federal elements in a new political system has largely been ignored. A federal system, although admittedly complicated to initially implement in a war torn country, has a possibility of being a success in a country that is currently made up of several clan

3 An example of this is the general feeling toward the Ethiopian presence currently in Somalia as according to the BBC it seems to be the only 'glue' holding the Islamic militants' focus against a 'foreign aggressor' rather than resorting to infighting amongst each other. It is believed that once the planned Ethiopian withdrawal is complete that the security situation will continue to be in a critical situation (BBC News 2007)

4 As a result of this lack of communication with local NGO's local food markets and household entitlements were destabilised when emergency food flowed into the region. 
divisions. The decision to attempt to impose a certain type of political system where it is seemingly incompatible with Somalia's natural political layout is a mistake but to further ignore other viable possibilities asks serious questions of interveners and their motivations.

\section{Comparing the effect of international intervention}

In explaining the situation of relative peace in Somaliland and the lack thereof in Somalia, a comparison must be made between political developments in both regions and the effect that international organisations' conflict management has had. Mark Bradbury claims that after the government of Barre was overthrown in 1991 the Somali state effectively ceased to function as an administrative, ideological, juridical and territorial entity. He argues that the civil war challenged the idea that Somalia was an ethnically homogenous state and since 1996 Somaliland has become one of the most stable regions in the horn of Africa (Bradbury 2003, 456). However despite being peaceful, democratic and declaring its independence the international community still refuses to view Somaliland as independent. However this has arguably helped to achieve the relative stability that it enjoys today compared to the south of the country. During the intervention in the early 1990's the international community continued to work under the auspices that Somalia was one country and therefore treated it as a single entity, having two significant results. Firstly it meant that as treating it as a single country the naivety of the interveners to concentrate their actions in Mogadishu meant that outside the capital and the surrounding area their efforts had very little effect. Despite this Somaliland has demonstrated over the years a remarkable ability to deal with challenges that threaten its stability, for instance since the day the presidential election results were announced in 2003 the public made it clear that it was opposed to a return to violence as a way of dealing with the political process (Bradbury et al 2003, 471). In Somaliland the absence of a central government in Mogadishu has led to the creation of decentralised, regional governments supported by traditional leaders and civil society groups that are helping to rebuild their country from the ground up (Somalia-Canada research institute 1999). This itself is an indication that a system similar to federalism can work in a society such as exists in Somalia, making a federal solution to political problems a seemingly viable alternative which should be investigated.

To the international community, despite there being more than a decade of civil war in southern Somalia, the Somali state survives as a judicial entity because they deem it so, not because it is recognised as such by all Somalis (Bradbury et al 2003, 475). In contrast Somaliland does not gain this right because it is not controlled by a central government, but it is this lack of recognition that has worked in Somaliland's favour. The international community is still focused on creating a central democratic 
government in Somalia and although the 2008 Djibouti peace process did initiate a new dialogue it has accomplished little in its short lifetime, not least because the parts of the Islamist insurgency that have the most guns and territory are not participants in the process (International Crisis Group 2008, 1). This is an example of how the international community refrains from allowing domestic politics in a country of interest to develop political norms that are different to western demands. By dragging their feet on the subject of Somaliland independence the international community are failing to realise that the future of Somalia is being created now through the decentralised regional administration (Somalia-Canada research institute 1999). However evidence still shows that the international community are still pushing for a centralised government and even backing another intervention force to aid the peace process (BBC 2007). It is ironic that western states refuse to acknowledge the possibility of a federal solution to the political problem despite the United States and Germany being constitutionally federalist.

However how is it possible that Somaliland, not intrinsically linked with foreign intervention, does not show the same amount of violent societal cleavages that the south has become so well known for and a level of reconciliation when there is a lack of central government? Is there simply such a stark and fundamental difference between the two societies, ignored by the outside world, which can explain the relative difference in fortunes between the two areas? A significant part of this question can be answered by looking at the history of the two states and how as a unit there are correlations between the way each entity was governed whilst under colonial rule and its present condition. William Reno outlines the economic differences between British Somaliland and Italian Somalia by noting that while Italian Somalia depended upon subsidies to underwrite exports and maintain state agencies, officials in British Somaliland insisted that the colony remain undisturbed and get by with a tiny state apparatus. Thus Somali regions experienced very different legacies of colonial rule, depending on whether they were included in Italian or British realms (Reno 2006, 152154). He notes that the significance of colonial and nationalist policies lay in providing political actors with the tools to become violent entrepreneurs as these policies weakened local capacity to resist this process.

In British Somaliland the British state left much of the politics of the country the way it was without interfering in local clan structures, however in Somalia the Italians had a much more hands on approach to governing their territory and in doing so changed the dynamics of the power structures to be more central, eroding the influence clan leaders had causing a power struggle that led to the civil war (Reno 2006, 148-152). Significantly UN/US forces have ignored these trends and instead insist on continuing down a similar path to political structures that the Italians proved cannot lead to sustainable peace. The lack of international influence in Somaliland has meant that the population can revert back to stabilised, familiar clan politics where reconstruction and 
reconciliation have largely been achieved from the resources and resourcefulness of 'Somalilanders' themselves (Bradbury 2003, 458).

\section{Conclusion}

In conclusion there are many different dynamics to the explanation of why there is relative peace in Somaliland compared to the rest of Somalia; arguably however most of the explanation falls on the actions of the international community whilst dealing with Somalia's difficulties. An apparent ignorance from international actors on political realities in Somalia, neglecting of possible federal political solutions demonstrating a single-minded attitude on how Somalia should be politically organised and failure to learn lessons from the past contribute toward the explanation of the two areas' differences. Almost a decade after the collapse of the centralised Somali state Somaliland has become a haven of peace in a conflict ridden horn of Africa, but still yet to be recognised by the international community, hindered by an international media that focuses entirely on the inter-clan militia violence in central and southern areas (Somalia-Canada research institute 1999). The level of reconciliation achieved requires significant analysis to ascertain whether other political junctures such as federalism would be more worthwhile to pursue. However developments have made the choices for the international community clear if they want to attain peace: either develop pragmatic responses to Somaliland's demand for self-determination therefore be able to impose a more flexible political constitution or continue to insist upon the increasingly abstract notion of the central unity and territorial integrity of the Somali Republic which displays no indicators of being successful (International Crisis Group 2003). 


\section{References}

[1] Ahmed, I. I., and Green, R. H. 1999, "The Heritage of War and State Collapse in Somalia and Somaliland: Local Level Effects, External Interventions and Reconstruction" in Third World Quarterly, vol. 20, no. 1, pp. 113-127.

[2] BBC News 2007: "Best Chance' for Somalia peace", retrieved from http://news.bbc.co.uk/1/hi/world/africa/6275783.stm (April 2011).

[3] Bradbury, M., Abokor, A. \& Yusuf H. 2003, "Somaliland: Choosing Politics over Violence" in Review of African Political Economy, vol. 30, no. 97, 455-478.

[4] Brune, L. H. 1998, The United States and post-cold war interventions: Bush and Clinton in Somalia, Haiti and Bosnia 1992-1998, Claremont, CA: Regina Books.

[5] Dobbins, J. et al 2003, Americas Role in Nation Building: From Germany to Iraq, Santa Monica, CA :Rand Publishing.

[6] International Crisis Group 2008, "Somalia: To Move beyond the Failed State", in Africa report No. 147, (Nairobi/Brussels, Dec 2008) retrieved from http://www.crisisgroup.org/ /media/Files/africa/horn-ofafrica/somalia/Somalia\%20To\%20Move\%20Beyond\%20the\%20Failed\%20Stat e.ashx (April 2011)

[7] International Crisis Group 2003, "Somaliland: Democratisation and its Discontents" in Africa Report no. 66 Nairobi/Brussels. Retrieved from http://www.crisisgroup.org/ /media/Files/africa/horn-of-

africa/somalia/Somaliland\%20Democratisation\%20and\%20lts\%20Discontents. ashx (April 2011)

[8] FitzGerald, V., Stewart, F., Venugopal, R. (eds) 2006, Globalisation, Violent Conflict and Self-Determination, Basingstoke: Palgrave Macmillan.

[9] Mayall, J. et al. 1996, The New Interventionism 1991-1994: United Nations Experience in Cambodia, Former Yugoslavia and Somalia, Cambridge: Cambridge University Press.

[10] Posner, D. 2004, "Civil Society and Reconstruction" in When States Fail: Causes and Consequences, ed. Rotberg, R.I., Princeton: Princeton University Press.

[11] Reno, W. 2006, "Somalia: State Failure and Self-determination in the Shadow of the Global Economy" in Globalisation, Violent Conflict and SelfDetermination, ed. FitzGerald, V., Basingstoke: Palgrave Macmillan, p. 147178.

[12] Somalia-Canada Institute for Research and Development and Partnership Africa Canada 1999, "Somalia: Peace and development", retrieved from http://www.africa.upenn.edu/Urgent Action/apic 91299.html (April 2011) 